KAMIL Mania

\title{
O PRAWIDŁOWYM KSZTAŁTOWANIU POSTANOWIEŃ W REGULAMINIE PRZYZNAWANIA POMOCY MATERIALNEJ
}

Wstęp

Przepisy ustawy z dnia 27 lipca 2005 r. - Prawo o szkolnictwie wyższym $^{1}$ (dalej: p.sz.w.), w zakresie regulującym system pomocy materialnej dla studentów i doktorantów, nie są jednolite. Zawierają one jedynie ogólne postanowienia odnoszące się do świadczeń pomocy materialnej, przesłanek, na podstawie których studenci i doktoranci mogą się o nie ubiegać, oraz organów przyznających świadczenia. Szczegółowe unormowania ustawodawca powierzył wewnętrznym regulaminom stypendialnym, które zgodnie $\mathrm{z}$ art. 186 p.sz.w. powinny zawierać informacje na temat kryteriów, trybu udzielania świadczeń materialnych oraz wszelkie wzory wniosków będących formalną podstawą ich przyznania.

Celem artykułu będzie nie tylko przedstawienie ogólnego pojęcia regulaminu jako aktu prawa zakładowego oraz przełożenie go na grunt szkolnictwa wyższego. Autor spróbuje odpowiedzieć na pytanie, jakie postanowienia powinny znaleźć się w przedmiotowym regulaminie, a które z nich, z powodu sprzeczności z ustawą i powszechnie obowiązującym prawem, nie powinny wiązać studentów i doktorantów ubiegających się o pomoc materialną. Poniższe dywagacje będą opierały się na przykładach z orzecznictwa sądów administracyjnych oraz poglądach wyrażanych w piśmiennictwie z zakresu szkolnictwa wyższego.

\footnotetext{
* Magister, Katolicki Uniwersytet Lubelski Jana Pawła II.

1 Dz.U. z 2012 r. poz. 572 ze zm.
} 


\section{O regulaminach w ogólności}

R. Raszewska-Skałecka uważa, że samo pojęcie regulaminu w teorii prawa nie jest rozumiane jednolicie, jednakże za najbardziej odpowiednie należałoby przyjąć takie, które określa regulamin jako zbiór przepisów, skierowany do określonej grupy ludzi, normujący zasady postępowania lub pracy organu państwowego, instytucji, zakładu lub urządzenia, wydany przez organ do tego upoważniony ${ }^{2}$. Z powyższej definicji można wyodrębnić elementy składające się na konstrukcję regulaminu: podmiot regulaminu oraz jego przedmiot.

Próbując określić podmiot regulaminu, należy podnieść, że normy, które on zawiera, skierowane są do dwóch kategorii adresatów: organów zakładu oraz sfery jego użytkowników. Organem zakładu będzie co do zasady podmiot uprawniony do wydawania regulaminu. Natomiast adresatami norm są jego użytkownicy (destynariusze) oraz, w drodze wyjątku inne osoby, które znalazły się na terenie zakładu ${ }^{3}$. Co do aspektu przedmiotowego regulaminu, to stwierdzić można, że jest on ograniczony wyłącznie do sfery działalności zakładu ${ }^{4}$. Za potwierdzeniem tej tezy przemawiają trzy grupy ogólnych postawień spotykanych w regulaminach. Są to:

a) postanowienia dotyczące określenia celów zakładu i jego pozycji w stosunkach $\mathrm{z}$ innymi organizacjami państwowymi, a szczególnie $\mathrm{w}$ jego stosunkach z organami nadzorczymi;

b) postanowienia odnoszące się do wewnętrznego funkcjonowania zakładu i normowania stosunków między organami wewnętrznymi zakładu oraz rozstrzygania sprawy upoważnień do występowania w imieniu zakładu; c) postanowienia odnoszące się do stosunku organów zakładu, do jego użytkowników, konstruując pozycję użytkownika zakładu przez określenie jego praw i obowiązków ${ }^{5}$.

Wreszcie regulamin może być pojmowany jako źródło prawa wewnętrznego, którego normy obowiązują na obszarze danego zakładu. Wśród tych norm można wyróżnić: normy proceduralne, ustrojowe oraz materialne. Przepisy regulaminów określające normy procesowe skupiają się na trybie postępowania przy podejmowaniu aktów wewnętrznych i ich zaskarżaniu przez adresatów. Normy o charakterze ustrojowym tworzą organy zakładowe, określają strukturę organizacyjną, zakres działania oraz zachodzące

2 R. Raszewska-Skałecka, Statut i regulamin zakładu administracyjnego jako źródła prawa, Łódź 2007, s. 90.

3 Tamże, s. 201-202.

${ }^{4}$ W. Zakrzewski, Zakres przedmiotowy i formy działalności prawotwórczej, Warszawa 1979, s. 220 .

${ }^{5}$ J. Starościak, Studia z teorii prawa administracyjnego, Warszawa 1967, s. 124. 
w nich procesy stanowiące podstawę do określenia ich zadań ${ }^{6}$. Natomiast normy prawa materialnego regulują szeroko rozumiane prawa i obowiązki użytkownika (destynariusza) zakładu, zarówno wobec zakładu, jak i jego organów. Przez pryzmat tych ostatnich będą rozpatrywane kolejne kwestie zawarte w niniejszym opracowaniu.

\section{O regulaminach w szkole wyższej}

Szkoły wyższe postrzegane są jako zakłady publiczne. Ich głównym zadaniem jest świadczenie usług o szczególnym znaczeniu społecznym, $\mathrm{w}$ tym wypadku wymienionych w art. 13 p.sz.w. Powyższe zadania, bez wątpienia, muszą być wykonywane zgodnie z pewnym zespołem norm prawnych, które regulują stosunki prawne z udziałem szkoły wyższej, ustanowionych na obszarze tego zakładu ${ }^{7}$.

Przekładając definicję R. Raszewskiej-Skałeckiej na grunt szkolnictwa wyższego, należy stwierdzić, że regulamin obowiązujący w uczelni wyższej powinien być oparty na szczegółowych zagadnieniach związanych z uprawnieniami i obowiązkami członków danej wspólnoty akademickiej ${ }^{8}$. Jego postanowienia mają charakter generalny, co skutkuje tym, że ich adresatem jest zakreślona ogólnie grupa studentów i doktorantów ${ }^{9}$. Prawo o szkolnictwie wyższym przewiduje trzy regulaminy, które bezwzględnie powinny obowiązywać w uczelni wyższej:

a) regulamin studiów oraz regulamin studiów doktoranckich;

b) regulamin określający zwiększenie stypendium doktoranckiego z dotacji projakościowej;

c) tzw. regulamin stypendialny, określający szczegółowe zasady przyznawania świadczeń $\mathrm{z}$ funduszu pomocy materialnej.

Zgodnie z art. 160 i n. oraz art. 196 ust. 6 p.sz.w. regulamin studiów oraz regulamin studiów doktoranckich zawierają postanowienia odnoszące się do organizacji oraz toku studiów, w tym związanych z nim praw i obowiązków studenta oraz doktoranta. Drugi, regulujący sprawy doktorantów, dotyczy trybu przyznawania zwiększenia stypendium doktoranckiego z dotacji projakościowej. Trzeci, będący przedmiotem niniejszego opracowania, to regulamin z art. 186 p.sz.w., dotyczący ustalania wysokości, przyznawania

\footnotetext{
${ }^{6}$ R. Raszewska-Skałecka, Statut i regulamin..., s. 285-286.

7 Tamże, s. 62.

${ }^{8}$ R. Raszewska-Skałecka, Miejsce statutu i regulaminu zakładu administracyjnego w systemie źródet prawa. Kwestie wybrane, "Przegląd Prawa i Administracji” 2007, t. LXXXVII, s. 270.

9 P. Dańczak, Decyzja administracyjna w indywidualnych sprawach studentów i doktorantów, Warszawa 2015, s. 35.
} 
i wypłacania świadczeń pomocy materialnej dla studentów i doktorantów. Jego uniwersalna definicja znajduje zastosowanie zarówno w literaturze przedmiotu, jak i w orzecznictwie. Idąc za dwoma wyrokami sądów administracyjnych, należy stwierdzić, że „regulamin pomocy materialnej jest aktem administracyjnym o charakterze normatywnym, wewnątrzzakładowym, który reguluje prawa i obowiązki podmiotów będących jego użytkownikami. Nie jest on tym samym dokumentem, który jest przeznaczony do obiegu wewnętrznego i którego podpisanie nie wywołuje żadnych skutków prawnych dla studenta i uczelni" ${ }^{10}$, ani „oświadczeniem woli osoby prawnej, jaką jest uczelnia wyższa"11.

\section{O kwestiach technicznych regulaminu z art. 186 p.sz.w.}

Regulacja art. 186 ust. 1 p.sz.w. przekazuje kompetencje dotyczące ustalenia szczegółowego regulaminu przyznawania świadczeń pomocy materialnej rektorowi, który robi to w porozumieniu $\mathrm{z}$ samorządem studenckim lub samorządem doktorantów. Samo pojęcie „porozumienie” może oznaczać trzy sytuacje: jednomyślność obu podmiotów, zgodę samorządu na regulamin zaprojektowany i przedstawiony przez rektora lub zgodę rektora na regulamin zaprojektowany i przedstawiony przez samorząd ${ }^{12}$. Odnośnie do wspomnianego przepisu należy zwrócić uwagę także na dwie dodatkowe kwestie. Po pierwsze, rolę rektora i samorządów w ustalaniu regulaminu oraz po drugie, tryb uchwalania powyższego aktu. Nie po raz pierwszy na gruncie przepisów Prawa o szkolnictwie wyższym przekazano kolejną już kompetencję odnoszącą się do pomocy materialnej rektorowi. Oprócz wspomnianego ustalania regulaminu, rektor, również w porozumieniu z organem samorządu, dokonuje podziału dotacji na stypendia i zapomogi. Jako organ pierwszej instancji to rektor przyznaje stypendia rektora dla najlepszych studentów/doktorantów (a w przypadku braku jednostek organizacyjnych w danej uczelni - wszystkich świadczeń, także tych o charakterze socjalnym). Jest również organem odwoławczym od decyzji wydanych przez kierownika podstawowej jednostki organizacyjnej. Wobec powyższego należy zwrócić uwagę na wzmocnioną ostatnimi czasy pozycję naczelnego organu uczelni wyższej w zakresie przyznawania świadczeń pomocy materialnej. Niewątpliwie ma to gwarantować stabilność i działania zgodne z prawem w zakresie

\footnotetext{
${ }^{10}$ Wyrok WSA w Opolu z dnia 12 marca 2013 r., II SA/Op 17/13, CBOSA.

11 Wyrok NSA z dnia 29 stycznia 2013 r., I OSK 2746/12, CBOSA.

12 K. Dąbrowski, [w:] M. Czuryk, M. Karpiuk, J. Kostrubiec (red.), Prawo o szkolnictwie wyższym po nowelizacji. Komentarz praktyczny, Warszawa 2015, s. 244.
} 
pomocy materialnej, nawet jeśli uczelnia nie decyduje o dystrybucji pieniędzy pochodzących z budżetu państwa. Inną rolę w przedmiotowej procedurze pełni właściwy organ samorządu. Zgodnie z art. 202 ust. 5 i art. 209 ust. 5 p.sz.w. jego ustawowym zadaniem jest prowadzenie działalności w zakresie spraw studentów i doktorantów w zakresie socjalno-bytowym i kulturalnym. Co do pojęcia spraw z zakresu świadczeń pomocy materialnej, to bez wątpienia należą one do kategorii spraw studenckich i doktoranckich (aspekt podmiotowy i przedmiotowy). Z tego względu zrozumiałe jest włączenie przez ustawodawcę roli samorządu studentów i doktorantów w ustalanie regulaminu z art. 186 p.sz.w. Należy także zaznaczyć, że w nowo utworzonej uczelni regulamin ustala wyłącznie rektor. Przepis ten jest o tyle zrozumiały, że niejako wskazuje, że z początkiem funkcjonowania uczelni potrzeba co najmniej roku, aby zapewnić ukonstytuowanie się organu samorządu studenckiego i doktoranckiego. W przeciwnym wypadku może powstać problem oceny ważności regulaminu ustalonego samodzielnie przez rektora, a obowiązującego w dalszych latach istnienia uczelni, a tym samym legalności wydanych na jego podstawie decyzji w przedmiocie świadczeń pomocy materialnej ${ }^{13}$.

Na uwagę zasługuje także forma prawna przyjęcia (odpowiednie zarządzenie rektora) i czas obowiązywania regulaminu. Co do ostatniego, przepisy ustawy nie normują w prost, przez jaki okres przedmiotowy regulamin będzie obowiązywać. W praktyce regulaminy ustalane są bezterminowo, a dopiero zmiana lub uchylenie ich postanowień na wniosek rektora lub organu samorządu spowoduje, że część ich przepisów przestanie funkcjonować. Natomiast w przypadku uczelni nowo powstałej regulamin ustalany jest na okres roku, $\mathrm{i}$ to nie akademickiego, ale roku w rozumieniu przepisów prawa cywilnego. Obowiązuje on więc do dnia, który nazwą odpowiada początkowemu dniowi i biegu tego terminu ${ }^{14}$.

Konstruując regulamin z art. 186 p.sz.w., autorzy są zobligowani do stosowania reguł tworzenia aktów wewnętrznych. W tym aspekcie wypowiedział się WSA w Łodzi, który stwierdził, że „prawo kształtowania aktami wewnętrznymi, przez organy uczelni wyższej, sytuacji prawnej w tym praw i obowiązków studentów, pomimo jego autonomicznego charakteru, wymaga zachowania wszystkich standardów wpływających na jego wewnętrzną spójność, od której zależy następnie prawidłowe, tj. pozbawienie trudności interpretacyjnych, funkcjonowanie"15. Z powyższych względów należy wysunąć tezę, że regulamin powinien w swojej treści zawierać po pierwsze, szczegółowe postanowienia odnośnie do przyznawania świadczeń pomocy

13 Tamże, s. 258.

14 H. Izdebski, J.M. Zieliński, Prawo o szkolnictwie wyższym. Komentarz, Warszawa 2013, s. 452 .

${ }^{15}$ Wyrok WSA w Bydgoszczy z dnia 7 października 2009 r., II SA/Bd 322/09, CBOSA. 
materialnej, czyli takie, które są w sposób ogólny tylko zarysowane w Prawie o szkolnictwie wyższym oraz po drugie, postanowienia te powinny być tak skonstruowane, żeby ich interpretacja nie prowadziła do powstania dwóch lub więcej sposobów rozstrzygnięcia danej kwestii. Reasumując, prawidłowo skonstruowany regulamin to taki, który jednakowo traktuje studentów i doktorantów znajdujących się w tej samej sytuacji faktycznej i prawnej.

\section{O postanowieniach dotyczących świadczeń pomocy materialnej}

Z przepisu art. 186 p.sz.w. wynika, że regulamin przyznawania pomocy materialnej powinien zawierać szczegółowe kryteria i tryb udzielania świadczeń pomocy materialnej dla studentów, wzory stosownych wniosków i oświadczeń o przyznanie świadczeń pomocy materialnej, wzór oświadczenia o niepobieraniu świadczeń na innym kierunku studiów oraz unormowanie sposobu udokumentowania sytuacji materialnej studenta ${ }^{16}$.

Analizując kwestię szczegółowych kryteriów udzielania świadczeń, należałoby zacząć od tego, że przyjęte regulaminowe rozwiązania nie mogą naruszać ustawowych zasad przyznawania pomocy materialnej. Jak słusznie zauważa D. Dudek, uczelnie wyższe (publiczne i niepubliczne) pełnią rolę jedynie dystrybutora środków, zasilających fundusz pomocy materialnej, szczególnie z dotacji podmiotowej, stąd powinny bezwzględnie dostosować się do wymogów dyscypliny i norm prawnych, jakie wynikają z Prawa o szkolnictwie wyższym ${ }^{17}$. Czym innym jest zatem doprecyzowanie (uszczegółowienie) procedury, a czym innym tworzenie nowych przesłanek, nieznanych ustawie, a warunkujących przyznanie danego świadczenia ${ }^{18}$. Z powyższego wyni$\mathrm{ka}$, że uczelnia w uczelnianym systemie pomocy materialnej powinna ująć wszystkie formy pomocy materialnej przewidziane w Prawie o szkolnictwie wyższym ${ }^{19}$, jednakże ich szczegółowe kryteria nie powinny być sprzeczne z przepisami ustawy ${ }^{20}$.

W przypadku najpopularniejszego świadczenia pomocy materialnej, stypendium socjalnego, którego otrzymanie warunkowane jest posiadaniem odpowiedniego dochodu na osobę w rodzinie, do regulaminów nie mogą być wprowadzane inne „niż ustawowo przewidziane zasady ustalania dochodu

${ }^{16}$ D. Dudek, [w:] M. Pyter (red.), Prawo o szkolnictwie wyższym. Komentarz, Warszawa 2012, s. 930

17 Tamże.

18 J. Pakuła, Pomoc materialna dla studentów. Podręczny komentarz. Przegląd orzecznictwa. Wzory pism, Toruń 2013, s. 48.

19 Wyrok NSA z dnia 14 października 2009 r., I OSK 352/09, CBOSA.

${ }^{20}$ Wyrok WSA w Warszawie z dnia 28 listopada 2013 r., II SA/ Wa 1459/13, CBOSA. 
na osobę w rodzinie studenta". Przedmiotowy regulamin nie może zatem uzależniać otrzymania stypendium od ustalenia dochodu na osobę w rodzinie wnioskującego, na podstawie reguł innych niż przewidziane w ustawie o świadczeniach rodzinnych (dalej: u.ś.r.) ${ }^{21}$, o pomocy społecznej ${ }^{22}$ lub o podatku rolnym ${ }^{23}$. Regulaminy w swojej treści nie powinny także zawierać kryteriów, które nie mają podstaw w ustawie, np. odbieranie stypendium w przypadku wpisu warunkowego na kolejny semestr, opóźnionego zaliczenia roku studiów lub nieterminowego złożenia indeksu. Stosownie do art. 179 ust. 1 p.sz.w. jedynym kryterium przyznania tego stypendium jest trudna sytuacja materialna. Aspektem, na który wypadałoby także zwrócić uwagę, jest sposób udokumentowania wspomnianej trudnej sytuacji materialnej. Niewątpliwie jest to obowiązkowy element regulaminu. W tym wypadku, ustalając przedmiotowe zapisy, „rektor nie jest związany przepisami u.ś.r. Przedmiotowe przepisy stosuje się bowiem do pomocy materialnej dla studentów i doktorantów wyłącznie w zakresie określonym w art. 175 ust. 5 p.sz.w., tj. w zakresie tych przepisów, które dotyczą ustalania wysokości dochodu studenta, a nie jego dokumentowania"24 . Z powyższych względów regulamin przyznawania pomocy materialnej nie powinien skupiać się jedynie na dowodach z dokumentów (zaświadczeniach od organów administracji publicznej, orzeczeniach sądów, oświadczeniach strony i członków ich rodzin) i jednocześnie pozostawać w sprzeczności z zasadą otwartego postępowania dowodowego, zgodnie z którą jako dowód w postępowaniu należy dopuścić wszystko, co może się przyczynić do wyjaśnienia sprawy, a nie jest sprzeczne z prawem. W szczególności za dowód można przyjąć, ustalając trudną sytuację materialną wnioskującego, zeznania świadków czy w końcu przesłuchanie samej strony.

Wątpliwości mogą także budzić postanowienia związane ze zwiększeniem stypendium socjalnego z uwagi na zamieszkanie w domu studenckim lub obiekcie innym niż dom studencki. Wnioskujący, który ubiega się o przedmiotowy dodatek, powinien udokumentować fakt, że spełnia przesłanki z art. 182 p.sz.w., tj. np. przedkładając umowę najmu, w której znajdzie się chociażby miesięczna kwota czynszu. Nie ma jednak podstaw prawnych do żądania udokumentowania ponoszenia kosztów zamieszkania w obiekcie innym niż dom studencki od osoby, która zamieszkuje w nim nieodpłatnie ${ }^{25}$. Bezprawne i nad wyraz krzywdzące dla studentów i doktorantów są także zapisy związane z tym, że beneficjentom pomocy materialnej odbierano pra-

21 Dz.U. z 2015 r. poz. 114 ze zm.

22 Dz.U. z 2015 r. poz. 163 ze zm.

23 Dz.U. z 2013 r. poz. 1381 ze zm.

24 Wyrok WSA w Szczecinie z dnia 11 października 2006 r., II SA/Sz 430/06, CBOSA.

25 M. Kubiak, [w:] W. Sanetra, M. Wierzbowski (red.), Prawo o szkolnictwie wyższym. Komentarz, Warszawa 2013, s. 423. 
wo do otrzymywania dodatku w przypadku wyjazdu na część studiów za granicę lub w trakcie praktyk, jeśli uczelnia nie pokrywa kosztów zakwaterowania i wyżywienia. Przeby wanie na praktykach nie musi wcale oznaczać, że student czy doktorant nie ponoszą kosztów wynajmu pokoju w domu studenckim czy mieszkania.

Kolejną formą pomocy materialnej, którą regulamin powinien ustalać szczegółowo, jest stypendium rektora dla najlepszych studentów i doktorantów. Zgodnie z art. 181 p.sz.w. stypendium to może otrzymywać student, który uzyskał za rok studiów wysoką średnią ocen lub posiada osiągnięcia naukowe, artystyczne lub wysokie wyniki sportowe we współzawodnictwie krajowym. Maksymalna liczba studentów, którzy mogą je otrzymać, w myśl art. 174 ust. 4 p.sz.w., nie może być większa niż 10\% liczby studentów każdego kierunku studiów prowadzonego na uczelni.

Zaczynając od końca, można przyjąć w zapisach regulaminowych, że stypendium rektora dla najlepszych studentów będzie przysługiwało nie więcej niż 8\% liczby studentów. Takie rozwiązanie może automatycznie generować pytanie dotyczące przyczyn ograniczenia możliwości ubiegania się o to świadczenie. Tak jak w przypadku stypendium socjalnego i możliwości podwyższania dochodu i tym samym umożliwiania większej liczbie uprawnionych ubiegania się o to świadczenie (chociaż nieraz kosztem mniejszych jego kwot), tak i w przypadku stypendium rektora przedmiotowe ograniczenie analogicznie może sprawić, że mimo mniejszej liczby stypendiów ich wysokość wzrośnie, jednakże nie będzie mogła przekroczyć (łącznie ze stypendium socjalnym) 90\% kwoty najniższego wynagrodzenia zasadniczego asystenta ustalonego $\mathrm{w}$ przepisach o wynagradzaniu nauczycieli akademickich.

Większą wątpliwość mogą budzić zapisy odnoszące się do interpretowania przesłanek z art. 181 p.sz.w. Po pierwsze, regulamin nie może pomijać którejkolwiek z przesłanek wymienionych w powołanym przepisie. Jak słusznie zauważył NSA, „przyznanie uczelniom autonomii nie może bowiem naruszać konstytucyjnej hierarchii źródeł prawa. Można za to je skonkretyzować np. poprzez określenie dolnego progu średniej ocen, który trzeba osiągnąć, aby spełnić ustawową przesłankę «uzyskania za rok studiów wysokiej średniej ocen ${ }^{26 \prime \prime}$. Analogicznie regulamin w swojej treści nie może zawierać dodatkowych, nieprzewidzianych w ustawie, kryteriów przyznawania stypendium rektora dla najlepszych studentów, np. osiągnięć w pracy organizacyjno-społecznej na rzecz środowiska akademickiego ${ }^{27}$. Kryteria otrzymania stypendium mogą być zastosowane zarówno łącznie, jak i selektywnie. Co za

${ }^{26}$ Wyrok NSA z dnia 20 sierpnia 2014 r., I OSK 959/14, CBOSA.

${ }^{27}$ M. Kubiak, G. Winiarz, [w:] W. Sanetra, M. Wierzbowski (red.), Prawo o szkolnictwie wyższym. Komentarz, Warszawa 2013, s. 422. 
tym idzie, rektor „ma prawo obwarować przyznanie stypendium w sposób dalej idący, niż tylko warunkiem uzyskania wysokiej średniej ocen w roku poprzedzającym złożenie podania"28. Przykładowo przedmiotowe świadczenia można uzyskać, spełniając kryterium wysokiej średniej łącznie z kryterium osiągnięcia naukowego. Trzeba także podnieść, że mimo to uczelnia $\mathrm{w}$ ramach swojej autonomii nie ma obowiązku zamieszczenia $\mathrm{w}$ regulaminie wszystkich wymienionych w ustawie kryteriów ${ }^{29}$.

\section{O terminach}

Istotną kwestią związaną z przyznawaniem świadczeń pomocy materialnej są oznaczone w dniach terminy, do których osoba uprawniona powinna złożyć wniosek, aby spełnić jeden z wymogów formalnych warunkujących otrzymanie świadczenia. Ustawodawca w Prawie o szkolnictwie wyższym nie wprowadził w żadnym z przepisów, ani kształtujących zasady przyznawania świadczeń, ani regulujących poszczególne świadczenia, postanowień odnoszących się do nich. Idąc za J. Pakułą, należy zauważyć, że „w ostatnich latach było powszechną praktyką, że uczelnie w swoich regulaminach wprowadzały terminy zawite, co skutkowało tym, że taki wniosek nie był rozpatrywany, a student stracił prawo do pomocy materialnej przynajmniej na semestr, jeśli nie na rok akademicki. Jako uzasadnienie takiego postępowania podawano, że chodzi tu o racjonalne gospodarowanie budżetem przeznaczonym na pomoc materialną. Jeśli bowiem na początku roku akademickiego wiadomo, ile jest osób uprawnionych, to łatwiej można podzielić te środki. Taki termin zawity skutecznie zmniejszałby ryzyko wystąpienia dodatkowych wydatków"30. Pogląd ten został szeroko zaaprobowany w judykaturze. Jak stwierdził NSA, „przepis art. 186 ust. 1 nie stanowi ustawowego upoważnienia rektora do wprowadzania $\mathrm{w}$ regulaminie materialno prawnego terminu zawitego przyznania stypendium, którego upływ udaremnia przyznanie świadczenia; jedyne kryterium otrzymania stypendium zostało określone $\mathrm{w}$ art. 181 ust. 1 p.sz.w., a odmowa jego przyznania $\mathrm{z}$ uwagi na przekroczenie terminu zawitego jest rażącym naruszeniem prawa"31. Podobny pogląd podziela WSA w Szczecinie, który dodatkowo podnosi, że "gdyby intencją ustawodawcy było wprowadzenie ograniczenia czasowego

${ }^{28}$ Wyrok WSA w Szczecinie z dnia 22 lipca 2010 r., II SA/Sz 184/10, CBOSA.

${ }^{29}$ M. Kubiak, G. Winiarz, [w:] W. Sanetra, M. Wierzbowski (red.), Prawo o szkolnictwie..., s. 422

30 J. Pakuła, Pomoc materialna..., s. 49.

31 Wyrok NSA z dnia 5 grudnia 2006 r., I OKS 646/06, CBOSA. 
do składania wniosków o stypendium, to niewątpliwie taki zapis znalazłby się $\mathrm{w}$ prawie materialnym, przepisach ustawy ${ }^{32}$. Wobec powyższego, zamieszczony w regulaminie przepis, powinien określać, że dany termin „nie ma charakteru procesowego, lecz jest to termin zawity"33.

Reasumując powyższą kwestię, najlepszym rozwiązaniem, które z jednej strony nie będzie sprzeczne $\mathrm{z}$ prawem i zapewni poczucie bezpieczeństwa prawnego, zarówno tym wnioskującym, którzy złożyli wniosek w terminie, jak i tym, którzy tego nie dokonali, byłoby uzależnienie stosowania terminu zawitego od rodzaju świadczenia. Jeśli chodzi o stypendium socjalne, to podstawą jego przyznania jest trudna sytuacja materialna wnioskującego. Może tak się zdarzyć, że student na początku roku akademickiego podejmuje pracę i w jego rodzinie nie występuje trudna sytuacja materialna. Dopiero gdy w trakcie roku akademickiego ów student straci pracę, jego dochód po przeliczeniu będzie podstawą do przyznania stypendium socjalnego. Z tego względu przytoczone orzeczenia mogą zasługiwać na uwzględnienie. Inaczej sytuacja będzie wyglądać w przypadku stypendium rektora. Niewątpliwie postępowanie w przedmiocie jego przyznania ma charakter konkursowy, a kończy je ogłoszona lista rankingowa zawierająca listę studentów, którzy złożyli wniosek wraz z otrzymanymi punktami za zdobyte osiągnięcia. W takim wypadku na aprobatę zasługuje pogląd, że na użytek tego postępowania uzasadnienie jest ustanowienie terminu procesowego, choćby z uwagi na to, że nabór co miesiąc nowych wniosków, a co za tym idzie, ciągła zmiana listy rankingowej, spowodowałyby niemożność ustalenia maksymalnie 10\% liczby studentów na danym kierunku studiów oraz wypłaty świadczenia.

\section{Podsumowanie}

Powyższe przykłady niedozwolonych postanowień zawieranych w regulaminach przyznawania i wypłacania pomocy materialnej pokazują, że uczelnie wyższe nie do końca radzą sobie z konstruowaniem wewnętrznych aktów prawnych zgodnych z ustawą. Zapisy niemające podstawy w Prawie o szkolnictwie wyższym skutkują nieprawidłowościami związanymi z procedurą przyznawania pomocy materialnej, tym samym naruszając zasadę pewności prawa i burząc zaufanie do jego instytucji. Aby do tego nie doprowadzić, regulamin powinien mieć charakter spójny, przejrzysty i konsekwentny. Przy jego konstruowaniu należy stosować zasadę poprawnej

\footnotetext{
${ }^{32}$ Wyrok WSA w Szczecinie z dnia 21 października 2009 r., II SA/ Sz 281/09, CBOSA.

${ }^{33}$ Wyrok WSA w Łodzi z dnia 9 czerwca 2008 r., III SA/Łd 145/08, CBOSA.
} 
legislacji i logiki prawniczej. Należy także unikać pojęć niedookreślonych, których Prawo o szkolnictwie wyższym używa już i tak w nadmiarze.

Podsumowując, należy podnieść, że regulamin przyznawania pomocy materialnej jest na tyle ważnym wewnętrznym aktem zakładu administracyjnego, jakim jest szkoła wyższa, że jego szczegółowe postanowienia powinny w sposób zrozumiały i zgodny z prawem oddziaływać na studentów i doktorantów danej uczelni. Spełnienie tego postulatu bez wątpienia ograniczy procedury odwoławcze i częste skargi do sądów administracyjnych, a jednocześnie, w sposób budzący zaufanie do jego autorów, przybliży zawiłe i skomplikowane aspekty systemu pomocy materialnej.

Słowa kluczowe: doktorant, pomoc materialna, rektor, regulamin, student, stypendium, szkoła wyższa.

\section{Bibliografia}

Czuryk M., Karpiuk M., Kostrubiec J. (red.), Prawo o szkolnictwie wyższym po nowelizacji. Komentarz praktyczny, Warszawa 2015.

Dańczak P., Decyzja administracyjna w indywidualnych sprawach studentów i doktorantów, Warszawa 2015.

Izdebski H., Zieliński J.M., Prawo o szkolnictwie wyższym. Komentarz, Warszawa 2013. Pakuła J., Pomoc materialna dla studentów. Podręczny komentarz. Przeglad orzecznictwa. Wzory pism, Torun 2013.

Pyter M. (red.), Prawo o szkolnictwie wyższym. Komentarz, Warszawa 2012.

Raszewska-Skałecka R., Miejsce statutu i regulaminu zakładu administracyjnego w systemie źródeł prawa. Kwestie wybrane, „Przegląd Prawa i Administracji” 2007, t. LXXXVII.

Raszewska-Skałecka R., Statut i regulamin zakładu administracyjnego jako źródła prawa, Łódź 2007.

Sanetra W., Wierzbowski M. (red.), Prawo o szkolnictwie wyższym. Komentarz, Warszawa 2013.

Starościak J., Studia z teorii prawa administracyjnego, Warszawa 1967.

Zakrzewski W., Zakres przedmiotowy i formy działalności prawotwórczej, Warszawa 1979.

\section{Orzecznictwo}

Wyrok NSA z dnia 5 grudnia 2006 r., I OKS 646/06, CBOSA.

Wyrok NSA z dnia 14 października 2009 r., I OSK 352/09, CBOSA.

Wyrok NSA z dnia 29 stycznia 2013 r., I OSK 2746/12, CBOSA.

Wyrok NSA z dnia 20 sierpnia 2014 r., I OSK 959/14, CBOSA. 
Wyrok WSA w Szczecinie z dnia 11 października 2006 r., II SA/Sz 430/06, CBOSA. Wyrok WSA w Łodzi z dnia 9 czerwca 2008 r., III SA/Łd 145/08, CBOSA.

Wyrok WSA w Bydgoszczy z dnia 7 października 2009 r., II SA/Bd 322/09, CBOSA. Wyrok WSA w Szczecinie z dnia 21 października 2009 r., II SA/ Sz 281/09, CBOSA. Wyrok WSA w Szczecinie z dnia 22 lipca 2010 r., II SA/Sz 184/10, CBOSA. Wyrok WSA w Opolu z dnia 12 marca 2013 r., II SA/Op 17/13, CBOSA.

Wyrok WSA w Warszawie z dnia 28 listopada 2013 r., II SA/ Wa 1459/13, CBOSA.

\section{THE PROPER SHAPING OF THE PROVISIONS IN THE RULES FOR GRANTING FINANCIAL AID}

\section{S u m m a r y}

Article in its content raises issues relating to one of the most important acts of an internal nature, functioning in the high school - the rules for granting financial aid. This aspect was presented through the prism of the general concept of the act, its features, as well as specialist literature and the jurisprudence of judicial administration. It was pointed out which provisions of the authors should be avoided, and that should apply so that the procedure of granting financial assistance took place in accordance with the law.

Key words: financial aid, high school, PhD student, rector, scholarship, Statute, student.

\section{О ПРАВИЯЬНОМ ФОРМИРОВАНИИ ПОСТАНОВЯЕНИЙ В РЕГЛАМЕНТЕ ПРИЗНАНИЯ МАТЕРИАЛЬНОЙ ПОМОЩИ}

$$
\text { Р е } з \text { ю м е }
$$

Резюме Статья в своем содержании касается вопросов, которые относятся к одному из важнейших юридических актов о внутреннем, функционирующем характере в вузе - регламенту признания материальной помощи. Данный аспект был представлен призмой общего понятия регламента, его признаков, а также специализированной литературы и судебного административного вынесения решения. Указано, каких постановлений авторы должны избегать, а которые должны придерживать, чтобы процедура признания материальной помощи происходила согласно положениям права.

Ключевые слова: аспирант, материальная помощь, ректор, регламент, студент, стипендия, вуз.

Tłum. na j. rosyjski Michał Mościcki 